\title{
Possible influence of social media on shaping the image of nurses on the Internet
}

\author{
Możliwości social media w kształtowaniu wizerunku pielęgniarek w Internecie
}

\section{Piotr Pawłowski' , Daria Makuch', Paulina Mazurek', Adrianna Bartoszek', Alicja Artych ${ }^{1}$, Beata Dobrowolska²}

'Studenckie Koło przy Katedrze Rozwoju Pielęgniarstwa, Wydział Nauk o Zdrowiu Uniwersytetu Medycznego w Lublinie/ Students'Scientific Association, Department of Nursing Development, Faculty of Health Sciences, Medical University of Lublin

${ }^{2}$ Katedra Rozwoju Pielęgniarstwa Wydział Nauk o Zdrowiu Uniwersytetu Medycznego w Lublinie/ Department of Nursing Development, Faculty of Health Sciences, Medical University of Lublin

CORRESPONDING AUTHOR/AUTOR DO KORESPONDENCJ:

Piotr Pawłowski

Studenckie Koło przy Katedrze Rozwoju Pielęgniarstwa, Wydział Nauk o Zdrowiu Uniwersytet yMedycznego w Lublinie

ul. Staszica 4/6, 20-081 Lublin

e-mail: pawlowskipiotr56@gmail.com

\section{STRESZCZENIE}

Słowa kluczowe:

ABSTRACT

Key words:

\section{MOŻLIWOŚCI SOCIAL MEDIA W KSZTALTOWANIU WIZERUNKU PIELEGNIAREK W INTERNECIE}

Wstęp. Współcześnie wizerunek zawodowy jest ważnym elementem tożsamości niemalże każdej profesji. Jego kształtowanie to proces trudny, zależny od wielu czynników, w tym między innymi wykorzystywanie nowych kanałów komunikacji, takich jak media społecznościowe, które w ostatnich latach stały się przestrzenią wyrażania opinii społecznej, także tej dotyczącej poszczególnych zawodów.

Cel pracy. Analiza możliwości wykorzystania social media w kształtowaniu wizerunku pielęgniarek w Internecie.

Materiał i metodyka. Badanie przeprowadzono wykorzystując metodę porównawczą. Przedmiot badań stanowiły strony (fanpage) związane ze środowiskiem zawodowym pielęgniarek na portalu społecznościowym Facebook.com, dobrane celowo według przyjętych kryteriów.

Wyniki badań. W czasie realizacji badań dostrzeżono różnice w strategii prowadzenia analizowanych stron (fanpage), uzależnione w głównej mierze od tematyki oraz celu publikowania treści. Aktualność, atrakcyjność i spójność wizualna charakteryzowała się wysokim poziomem. Pojawiające się na poszczególnych witrynach treści (posty) pisane były językiem dostosowanym do grupy odbiorców, z zachowaniem różnej częstotliwości publikacji. Strony tworzyły stałą społeczność obserwujących, starały się pozytywnie wpłynąć na wizerunek pielęgniarstwa w Polsce.

Wnioski. Treści publikowane w mediach społecznościowych mogą wpłynąć zarówno pozytywnie jak i negatywnie na obraz pielęgniarki w opinii społeczeństwa. Wśród czynników niekorzystanie wpływających na wizerunek pielęgniarek można wskazać m.in. obraźliwy język komentarzy, epatowanie negatywnymi cechami pielęgniarek. Pozytywny odbiór gwarantuje aktualna wiedza z zakresu pielęgniarstwa oraz podkreślanie kompetencji zawodowych.

wizerunek zawodowy, pielęgniarki, social media, Facebook.com

\section{POSSIBLE INFLUENCE OF SOCIAL MEDIA ON SHAPING THE IMAGE OF NURSES ON THE INTERNET}

Introduction. Nowadays, a professional image is an important element of the identity of individual professions. Its formation is a difficult process, dependent on many factors, including the use of new communication channels, such as social media, which in recent years have become a space for expressing social opinion, including those concerning individual professions.

Aim. The analysis of the possibilities of using social media in shaping the image of nurses on the Internet.

Material and methods. The study was carried out using the comparative method. The subject of the research were websites (fanpages) related to the professional environment of nurses on the social networking site Facebook.com, chosen deliberately according to the adopted criteria.

Findings. During the research, differences in the strategy of administering the analyzed websites were identified, depending mainly on the subject matter and purpose of publishing the content. The topicality, visual attractiveness and cohesion were characterized by a high level. The posts appearing on individual websites were written in the language of the recipients, with different publication frequency. The websites created a long-term group of recipients and tried to influence the image of nursing in Poland in a positive way. Conclusions. Content published on social media can affect both the positive and negative image of the nurse in the public opinion. Among the factors that do not affect the image of nurses can be indicated, among others, offensive language of comments and displaying negative traits of nurses. Positive reception guarantees current knowledge in the field of nursing and emphasizing professional competences. 


\section{INTRODUCTION}

Maintaining positive relations between the professional group and the environment, as well as shaping a credible image are big challenges that arise before the representatives of almost all professions, and in particular the group of professions of public trust. In view of the above, the nurses' environment cannot and will not remain passive in the face of transformations, related among other things to the change of communication channels, the development of new technologies, including social media.

According to the Polish Language Dictionary PWN (2013), the image is ,the way in which a person or thing is perceived and presented" [1]. Usually, it does not depend strictly on the person being evaluated, but often - on the society's beliefs, the stereotypes prevailing in it. Referring the aforementioned dependencies to the nurse profession, it can be stated that her image depends mainly on the nature of the relationship with the patient, her knowledge, experience, and her position in the internal hospital system [2].

Nowadays, apart from education and experience, each profession wishing to stand out with respect, recognition, authority, and thus a positive professional image must know the rules for its creation, with particular attention to the tools used, which should correspond to the preferences of the target groups [3].

It is worth noting that currently the creation of the social image of nurses is greatly influenced by traditional media ( $\mathrm{TV}$, radio, press) that use many different forms of communication: commercials, television programs, series. In this process, new technologies (Internet, smartphones, applications), including, above all, social media as the main communication channel on the Internet, play an increasingly important role [4].

Nowadays, the Internet has become a space for expressing yourself, your views, beliefs. As a result, Internet users are keen to get involved in social networking sites, opening personal profiles more and more.

Considering the fact that social media are so popular among Internet users, creating their own professional image, their potential should be properly exploited. This may in the future bring immeasurable image benefits, prevent media crisis, help create a community of reliable and loyal observers, confirming our authenticity [5]. The success can be provided by creating a blog, fanpage on Facebook.com or a channel on Twitter.com.

Interactive media is today a prerequisite for effective communication with the public, so it is invaluable to reach the right and responsive audience and build mutual relationships based on trust [6]. Communication with the use of social media has a more open and honest character, comparing to publications and information published in the area of websites. What is more, the number of fans, people watching the page is no longer the most important, while the active contact of Internet users with the author of the published content is more important. Recipients of posts and messages have specific expectations from their authors. They count on the openness of the sender, kindness, understanding, effective communication, propriety, as well as updated and reliable knowledge. The condition for the effectiveness of this communication activity, which is the creation of a nursing image, is mostly the personalization of the message, as well as conducting a two-way dialogue with the recipients. Therefore, it is vital to search for innovative methods of collecting, processing, transmitting and using information, e.g. in the form of articles, instructional films or blog entries [7].

\section{AIM}

The aim of the paper is to analyze social media possible influence on creating the image of nurses on the Internet, on the example of intentionally selected nursing websites (fanpages).

\section{MATERIALS AND METHODS}

The paper involved the comparative method, by making analysis of the fanpages concerning the professional nursing environment on Facebook.com. The analysis covered the following websites: Ogólnopolski Portal Pielęgniarek i Położnych/The Nationwide Polish Portal of Nurses and Midwives (1); Pielęgniarki/Nurses (2); Naczelna Izba Pielęgniarek i Położnych/The National Chamber of Nurses and Midwives (3); Polskie Towarzystwo Pielęgniarskie (PTP)/The Polish Nurses Association (PNA) (4); W czepku urodzona/The Born to Wear a Nurse's Cap (5); Stowarzyszenie Pielęgniarki Cyfrowe/ The Association of Digital Nurses (6); Pielęgniarki.com.pl/ Nurses.com.pl (7); Ogólnopolski Związek Zawodowy Pielęgniarek i Położnych/Polish Trade Union of Nurses and Midwives (8); Pielęgniarki i położne szanujcie się to inni będą Was szanować/Respect yourselves nurses and midwives, then others will respect you (9); Pielęgniarki na platformie/Nurses on the platform (10). The data characterizing the abovementioned websites is presented in Table 1. (as of 11/03/2019).

The selection criteria included the number of followers - likes (over 5,000) and their activity on the facebook.com portal. The websites were observed for a period of 30 days, in January, in two-day intervals, paying attention to the content published by both the creators and users of Facebook.com, in the form of posts, comments and entries. The analysis criteria adopted in the study comprised subject matter, purpose of the published content, attractiveness and visual coherence, language of the published content, website activity, creation of a long-term community of recipients and promoted professional image.

In February three authors analyzed the listed websites independently, and then, the obtained findings were discussed and agreed on following the above analysis criteria. 
Piotr Pawłowski, Daria Makuch, Paulina Mazurek, Adrianna Bartoszek, Alicja Artych, Beata Dobrowolska

Tab. 1. Characteristics of the data on the analyzed websites

\begin{tabular}{|c|c|c|c|c|c|}
\hline No. & Website name & Number of likes & Year of creation & Information & Website category \\
\hline 1. & $\begin{array}{l}\text { The Nationwide Portal of } \\
\text { Nurses and Midwives of } \\
\text { Poland }\end{array}$ & 52726 & 2006 & $\begin{array}{l}\text { The website of a nationwide organization whose aim is to make the } \\
\text { professional community and the society aware of the problems of } \\
\text { Polish nursing. }\end{array}$ & Community \\
\hline 2. & Nurses & 30127 & 2013 & $\begin{array}{l}\text { The site presents, often in a humorous manner, the reality of nurse's } \\
\text { work in Poland. The published content usually comes from external } \\
\text { websites. }\end{array}$ & $\begin{array}{l}\text { Medical industry } \\
\text { company }\end{array}$ \\
\hline 3. & $\begin{array}{l}\text { The National Chamber of } \\
\text { Nurses and Midwives }\end{array}$ & 11349 & 1991 & $\begin{array}{l}\text { Fanpage represents the official positions of the Self-Government of } \\
\text { Nurses and Midwives in Poland. }\end{array}$ & $\begin{array}{l}\text { Health and medicine; } \\
\text { Organization }\end{array}$ \\
\hline 4. & $\begin{array}{l}\text { The Polish Nurses } \\
\text { Association (PNA) }\end{array}$ & 10282 & 1957 & $\begin{array}{l}\text { The website is administered by the members of the oldest scientific } \\
\text { association in the field of nursing in Poland. Its fanpage is aimed } \\
\text { mainly to promote its activity. }\end{array}$ & Non-profit organization \\
\hline 5. & $\begin{array}{l}\text { The Born to Wear } \\
\text { a Nurse's Cap }\end{array}$ & 9976 & no data given & $\begin{array}{c}\text { The fanpage is administered by an active student of the 2nd degree of } \\
\text { nursing studies, whose aim is to promote the profession among the } \\
\text { young generation. } \\
\text { The editor is also the author of the book'W czepku urodzone / The } \\
\text { Born to Wear a Nurse's Cap). }\end{array}$ & $\begin{array}{l}\text { Public person; Health } \\
\text { and medicine; Nursing } \\
\text { school }\end{array}$ \\
\hline 6. & $\begin{array}{l}\text { The Association of Digital } \\
\text { Nurses }\end{array}$ & 7290 & 2017 & $\begin{array}{l}\text { The Association of Digital Nurses, through its website, conducts } \\
\text { activities aimed at increasing respect for the nurse and midwife } \\
\text { professions. }\end{array}$ & $\begin{array}{l}\text { Non-profit; Health and } \\
\text { medicine }\end{array}$ \\
\hline 7. & Nurses.com.pl & 6591 & 2017 & $\begin{array}{l}\text { The site focuses on practical aspects of the nurse profession, } \\
\text { presenting ready-made tools to facilitate work in the form of, among } \\
\text { others, medical calculators. Its administrators have also created } \\
\text { a database of nurses and midwives to consolidate the professional } \\
\text { environment. }\end{array}$ & $\begin{array}{l}\text { Website dedicated to } \\
\quad \text { education }\end{array}$ \\
\hline 8. & $\begin{array}{l}\text { Polish Trade Union of } \\
\text { Nurses and Midwives }\end{array}$ & 6458 & 1986 & $\begin{array}{l}\text { The website represents the largest nurses' trade union organization, } \\
\text { associating nurses from all over the country. Its goal is to fight for } \\
\text { decent working conditions for nurses and adequate gratification. }\end{array}$ & $\begin{array}{l}\text { Social organization; } \\
\text { Medical industry } \\
\text { company }\end{array}$ \\
\hline 9. & $\begin{array}{l}\text { Respect yourselves nurses } \\
\text { and midwives, then } \\
\text { others will respect you }\end{array}$ & 5448 & no data given & $\begin{array}{l}\text { The website's author admits that he is not a nurse. He is disappointed } \\
\text { with the treatment and the amount of remuneration for nurses and } \\
\text { midwives, which he tries to change through his activity on the site. }\end{array}$ & Community \\
\hline 10. & Nurses on the platform & 5274 & no data given & $\begin{array}{l}\text { The website aims to inform about the educational opportunities } \\
\text { dedicated to nurses and midwives. Fanpage also motivates to develop } \\
\text { professionally, take up postgraduate education, trainings and courses. }\end{array}$ & Education \\
\hline
\end{tabular}

\section{RESULTS}

The subject matter of the posts of analyzed fanpages is of a diverse character. Most of the analyzed websites focuses mostly on nursing proper as a practical activity and a scientific discipline associated with health care. The administrators promote information related to nurses' working conditions, law acts vital for the professional environment of nurses and midwives as well as the content related to opportunities for further postgraduate education and unlimited professional development. Fanpages present the latest information important for both nurses already working in the profession as well as for students and entrants of the art of nursing. During the observation of the websites, the predominant subjects involved the amount of remuneration for nurses and midwives, the professional image of these two professions, as well as the issues related to the activity of a given organization or people who are the authors of the fanpages.

Another criterion of the comparative analysis was the purpose of publishing the content, directly related to its subject matter. Almost all the fanpages qualified for research served an informative purpose, dedicated especially to the professions of nurses and midwives. The websites also presented dilemmas of nurse's daily work as perceived by a practitioner, which can be equated with a motivatio- nal goal that encourages a reflection on the nurse's profession, their contribution to the therapeutic process as well as personal negligence of the recipient. The content that touched upon the organization's activity, its publicity and the recruitment process, was related to the implementation of the statutory goals of the formal group, which the administrators of the website or fanpage represent.

While conducting the comparative analysis, it was noted that the main and prevailing goal of each website is to mobilize the public to discuss changes in the nurses' professional environment, pay attention to the situation of nurses in the country and to appreciate their contribution to the overall therapeutic process. The aforementioned is connected with the necessity of publishing the content leading to sensitizing, both the professional environment and the general public, to the problems and challenges of the nurse's work, with particular focus on the patient's rights and, above all, to the expectations of care recipients.

The attractiveness and visual coherence of the analyzed websites remain at a varied level. The great majority of graphics and photos was of high quality. Some of the fanpages make use of professional graphic software or help of specialists in the field. The dominant graphic form of the analyzed pages was infographics, which served the purpose to familiarize the user with the content quickly, without the necessity to read the whole post. Photos from 
the events realized by the organization were equally often published. Videos, recordings and live broadcasts were not a frequently used publishing control. The level of visual coherence of the websites depended on the level of professionalism of the website's graphic design. On analyzing fanpages in terms of their visual attractiveness, special attention was paid to the avatar (profile photo) and cover photo (background photo), they were adapted to the name and content of the website, however, the background photos in 4 cases were not adapted to the mobile version.

The language of the published content has a significant impact on the interest in added posts. In the situation where it is simple, it is characterized by adaptation to the group of recipients (nurses and midwives and other readers, unrelated to the medical environment), the whole site is perceived as professional, read more eagerly, and, above all, properly understood. The above-described style of virtual communication is applied by all the authors of the fanpages analyzed.

The activity of the analyzed websites varies, however, most of them publish content on average once every two or three days. There is also a fanpage in the study group that posts content with lower frequency, that is once every few weeks. A frequent occurrence is accumulation of the content on one day, especially in the situation when events that are important to the organization, with which the website is linked, take place, what can limit the group of recipients.

Creating a long-term community of recipients means conducting conversations in the comments space, encouraging followers to express their own opinions, asking questions, or sending messages directly to the website administrators, what is related to the indicator of response time of the editors. The great majority of currently active websites systematically makes efforts to engage 'followers' by responding to comments and questions asked. The website administrators usually responded within one day after receiving a message from the portal user. The aspect of creating the recipient community is also related to another website indicator measurable by the Facebook.com, namely, the score of the website performed by the viewer, on a scale of from 1 to 5 , where 1 is the lowest and 5 is the highest one. The average score of the analyzed websites ranged between 4.5 and 5.0.

The promoted professional image can be twofold, perceived either as a positive or negative one. Making a positive impression on the recipients regarding nursing is the mission of each of the analyzed fanpages. Their editors draw the attention of Facebook.pl users to the problems occurring not only in the nurses' professional environment, but also in the entire health care system, with special emphasis on the wellbeing of the patient, they make the society aware of the low prestige of the nurse profession, and above all highlight the huge contribution of the work of representatives of this profession to the overall therapeutic process of each patient. Positive perception of the website is also influenced by informing the public about the actual working conditions of nurses, about ongoing debates and discussions concerning proposed changes in the professional environment. Lack of political affiliation, acrimonious quarrels in the comments, the presence of appeals to stop the depreciation of the profession may affect the perception of a given website as well as the profession of a nurse. Solutions to problems of daily nursing practice appearing on fanpages, announcements about organized courses, trainings or specializations available, receive the highest number of responses, which is an indicator of the audience's greatest interest in the content proper.

The components whose presence may negatively affect the perception of nurses and midwives is, among other things, emanating the negative traits of nurses. This may contribute to difficulties in finding virtues of this profession by the Facebook.com community. Controversial content overflowing with of political issues, leading to misunderstandings and discussions mainly through comments, contribute to the deprivation of the nurse profession. A frequent accusation that is directed at the professional group is a lack of solidarity in the face of the challenges that it faces almost every day.

\section{DISCUSSION}

Social media has a big impact on creating the image of nurses. By means of the media, the authors have a chance to improve the image of this profession, eliminate stereotyping and create a real, reliable opinion about the profession of a nurse [8]. It also constitutes a tool for communicating with the external environment of the organization, including, in addition to nurses, people unrelated to this profession at all.

A vast majority of nurses and, above all, nursing students have an account on the Facebook.com portal, where information about the place of employment, the university or the current place of vocational education is posted. In addition, the people in question publish various types of content, provide comments, express opinions, and participate in controversial discussions. Each of the listed activities, despite being characterized by relative privacy, may affect the image of not only the person performing it, but also the organization that they represent. Verification of potential employees on the social networks by employers has become almost a standard. In connection with the above, all the activities of the individual should be carefully considered, so that they positively affect their future professional life and their own personal image on the Internet [9]. The results of this study show that the authors of the websites are aware of these issues, but the community 'gathered' around the website due to comments of various character and the language of a discussion often negatively affects their personal image, the image of the profession and that of a fanpage.

Social media in the assessment of the Royal College of Nursing $(\mathrm{RCN})$ is a great platform for exchanging experiences, expanding knowledge and creating expert communities that users can turn to in case of doubt. In the future it will bring benefits not only for the entire nurses' professional environment, but also for the patients themselves [10]. 
The use of social media also involves many threats that have been listed in the English language Guidance on using social media responsibly dedicated to nurses and midwives in the United Kingdom. It indicates that improper use of the Facebook.com tool may even result in the deprivation of the right to practice as a nurse by, among others: sharing confidential information, publishing pictures of patients or the health care system units without their consent, posting negative comments referring to patients, establishing contacts with patients without their prior consent et cetera [11]. In the analysis of the collected material, no such phenomenon was found. The standards regarding the protection of the privacy of the workplace, the intimacy of patients and all colleagues were also observed.

Using social media as an image-forming tool is associated with a high risk of making a mistake in the message-generating strategy that threatens to lose the professional image that has been developed so far. Moreover, an important element of the Internet publishing is compliance with the provisions of legal acts that normalize the issues of intellectual property protection or violation of personal rights. It should be emphasized that the users of social networking sites are not anonymous, and any unconstructive criticism and spreading the hate speech are a crime against art. 212 and art. 216 of the Penal Code. Moreover, the use of social networks at work, publishing photos from the health system units may involve the possibility of disciplinary dismissal. Therefore, it is crucial to minimize the use of social networks to the absolute minimum when performing activities resulting from the employment relationship, unless they are an indispensable tool for performing professional duties [9].
The comparative analysis conducted in this article shows that in comparison to Western European countries, the subject of social media in Polish nursing is an innovative subject. There are no Polish literature items explaining legal issues related to publishing content on Facebook.com, what indicates the need to intensify activities aimed at providing instructions for using social media by the professional environment of nurses and other professionals of the health care sector. The activities in question should be based on education. It is also worth considering the possibility of publishing a guide on the use of social media, based on the example of the item published by the Nursing and Midwifery Council (NMC) [11].

\section{CONCLUSIONS}

Both nurses working in real life and those present in virtual reality co-create the image of their own professional group. The nursing sites analyzed make use of the potential provided by social media in this matter. Among the factors that have a negative effect on the image of nurses, one can enumerate, among others, the offensive language of comments of people following the website or displaying negative traits of nurses. A positive impression is guaranteed by the updated knowledge in the field of nursing, showing real working conditions, as well as emphasizing professional competences and the involvement of nurses in the therapeutic process. There is a need for further research into the issue of shaping the image of the nurse profession in social media.

\section{Możliwości social media w kształtowaniu wizerunku pielęgniarek w Internecie}

\section{WPROWADZENIE}

Utrzymywanie pozytywnych relacji między grupą zawodową a otoczeniem, kształtowanie wiarygodnego wizerunku to duże wyzwanie, jakie pojawia się przed reprezentantami niemalże wszystkich profesji, a w szczególności grupy zawodów zaufania publicznego. W związku z powyższym, środowisko pielęgniarek nie może i nie pozostaje bierne w obliczu dokonywanych transformacji, związanych między innymi ze zmianą kanałów komunikacji, rozwojem nowych technologii, w tym także social media.

Według Słownika języka polskiego PWN (2013), wizerunek to „sposób, w jaki dana osoba lub rzecz jest postrzegana i przedstawiana” [1]. Zazwyczaj nie zależy on ściśle od ocenianego, często natomiast - od przekonań społeczeństwa, panujących w nim stereotypów. Odnosząc wyżej wymienione zależności do zawodu pielęgniarki, można stwierdzić, iż jej wizerunek uzależniony jest w głównej mierze od charakteru relacji $\mathrm{z}$ pacjentem, posiadanej wiedzy, doświadczenia, a także sprawowanego stanowiska $\mathrm{w}$ wewnętrznym systemie szpitala [2].

Współcześnie oprócz wykształcenia i doświadczenia, każda profesja chcąca wyróżniać się szacunkiem, uznaniem, autorytetem, a tym samym pozytywnym wizerunkiem zawodowym musi znać zasady dotyczące jego kreowania, ze szczególnym zwróceniem uwagi na wykorzystywane narzędzia, które winny odpowiadać preferencjom grupy docelowej [3].

Warto zwrócić uwagę na fakt, iż obecnie na kreowanie wizerunku społecznego pielęgniarek, ogromny wpływ mają tradycyjne media (TV, radio, prasa) wykorzystujące wiele różnorodnych form przekazu: reklamy, programy telewizyjne, seriale. W procesie tym, coraz większą rolę odgrywają również nowe technologie (Internet, smartphony, aplikacje) w tym przede wszystkim media społecznościowe, jako główny kanał komunikacji w Internecie [4].

Współcześnie Internet stał się przestrzenią do wyrażania siebie, swoich poglądów, przekonań. W związku 
z tym internauci bardzo chętnie zaangażują się w serwisy społecznościowe, coraz liczniej otwierając osobiste profile.

Biorąc pod uwagę fakt tak dużej popularności mediów społecznościowych wśród użytkowników Internetu, kreując własny wizerunek zawodowy należy odpowiednio wykorzystać ich potencjał. Może to w przyszłości przynieść niezmierne korzyści wizerunkowe, zapobiec kryzysowi medialnemu, pomóc w stworzeniu społeczności rzetelnych i lojalnych obserwatorów, potwierdzających naszą autentyczność [5]. Sukces zapewnić może stworzenie bloga, fanpage’a na portalu Facebook.com czy kanału na portalu Twitter.com.

Media interaktywne są dziś warunkiem skutecznej komunikacji ze społeczeństwem, a zatem nieocenione jest dotarcie do właściwej grupy odbiorców i budowanie wzajemnych relacji opartych na zaufaniu [6]. Komunikacja z wykorzystaniem mediów społecznościowych ma szczerszy i bardziej otwarty charakter, porównując do publikacji oraz informacji zamieszczanych w obszarze witryn internetowych. Co więcej, liczba fanów, osób obserwując daną stronę nie jest już najważniejsza, większe znaczenie ma aktywny kontakt użytkowników Internetu $\mathrm{z}$ autorem publikowanych treści. Odbiorcy komunikatów posiadają konkretne oczekiwania wobec ich autorów. Liczą na otwartość ze strony nadawcy, życzliwość, wyrozumiałość, efektywną komunikację, kulturę osobistą, a także aktualną i rzetelną wiedzę. Warunkiem skuteczności tego działania komunikacyjnego, jest przede wszystkim personalizacja przekazu, a także prowadzenie dwukierunkowego dialogu z odbiorcami. Konieczne jest wobec tego poszukiwanie nowatorskich metod gromadzenia, przetwarzania, przekazywania i użytkowania informacji, np. w postaci artykułów, filmów instruktażowych, czy wpisów na blogach [7].

\section{CEL PRACY}

Celem pracy jest analiza możliwości social media w kreowaniu wizerunku pielęgniarek w Internecie, na przykładzie celowo dobranych stron (fanpage'y) pielęgniarskich.

\section{MATERIAŁ I METODYKA}

W pracy wykorzystano metodę porównawczą, dokonując analizy fanpage'y, związanych ze środowiskiem zawodowym pielęgniarek na portalu społecznościowym Facebook. com. Analizą objęto następujące strony: Ogólnopolski Portal Pielegniarek i Położnych (1); Pielęgniarki (2); Naczelna Izba Pielęgniarek i Położnych (3); Polskie Towarzystwo Pielęgniarskie (PTP) (4); W czepku urodzona (5); Stowarzyszenie Pielegniarki Cyfrowe (6); Pielegniarki.com.pl (7); Ogólnopolski Związek Zawodowy Pielegniarek i Położnych (8); Pielegniarki i położne szanujcie się to inni będa Was szanować (9); Pielęgniarki na platformie (10). Dane charakteryzujące wymienione strony zawiera tabela 1 . (stan na 11.03.2019).

- Tab. 1. Charakterystyka poddanych analizie stron

\begin{tabular}{|c|c|c|c|c|c|}
\hline Lp. & Nazwa strony & Liczba like'ów & Rok powstania & Informacje & Kategoria strony \\
\hline 1. & $\begin{array}{l}\text { Ogólnopolski Portal } \\
\text { Pielęgniarek i Położnych }\end{array}$ & 52726 & 2006 & $\begin{array}{c}\text { Storna ogólnopolskiej organizacji, której celem jest uświadamianie } \\
\text { środowisku zawodowemu oraz społeczeństwu problemów polskiego } \\
\text { pielęgniarstwa. }\end{array}$ & Społeczność \\
\hline 2. & Pielęgniarki & 30127 & 2013 & $\begin{array}{l}\text { Storna przedstawia, często w żartobliwy sposób, realia pracy } \\
\text { pielęgniarki w Polsce. Treści publikowane pochodzą zazwyczaj } \\
\text { z obcych witryn. }\end{array}$ & $\begin{array}{l}\text { Firma z branży } \\
\text { medycznej }\end{array}$ \\
\hline 3. & $\begin{array}{c}\text { Naczelna lzba } \\
\text { Pielęgniarek i Położnych }\end{array}$ & 11349 & 1991 & $\begin{array}{c}\text { Fanpage reprezentuje oficjalne stanowiska Samorządu } \\
\text { Pielęgniarek i Położnych w Polsce. }\end{array}$ & $\begin{array}{l}\text { Zdrowie i medycyna; } \\
\text { Organizacja }\end{array}$ \\
\hline 4. & $\begin{array}{l}\text { Polskie Towarzystwo } \\
\text { Pielęgniarskie (PTP) }\end{array}$ & 10282 & 1957 & $\begin{array}{l}\text { Strona jest administrowana przez członków najstarszego w Polsce } \\
\text { stowarzyszenia naukowego w dziedzinie pielęgniarstwa. Fanpage } \\
\text { ma na celu głównie promocje jego działań. }\end{array}$ & Organizacja non profit \\
\hline 5. & W czepku urodzona & 9976 & brak danych & $\begin{array}{c}\text { Fanpage prowadzony jest przez aktywną studentkę kierunku } \\
\text { pielęgniarstwo (studia Il stopnia), której celem jest promowanie } \\
\text { zawodu wśród młodego pokolenia. } \\
\text { Redaktorka jest również autorem książki, „W czepku urodzone”. }\end{array}$ & $\begin{array}{l}\text { Osoba publiczna; } \\
\text { Zdrowie i medycyna; } \\
\text { Szkoła pielęgniarska }\end{array}$ \\
\hline 6. & $\begin{array}{c}\text { Stowarzyszenie } \\
\text { Pielęgniarki Cyfrowe }\end{array}$ & 7290 & 2017 & $\begin{array}{l}\text { Stowarzyszenie Pielęgniarki Cyfrowe prowadzi za pośrednictwem } \\
\text { swojej strony działania służące zwiększeniu szacunku do zawodów } \\
\text { pielęgniarki i położnej. }\end{array}$ & $\begin{array}{l}\text { Organizacja non profit; } \\
\text { Zdrowie i medycyna }\end{array}$ \\
\hline 7. & Pielegniarki.com.pl & 6591 & 2017 & $\begin{array}{c}\text { Strona skupia się na praktycznych aspektach zawodu pielęgniarki, } \\
\text { prezentując gotowe narzędzia ułatwiające pracę, w postaci między } \\
\text { innymi kalkulatorów medycznych. Administratorzy stworzyli także } \\
\text { bazę pielęgniarek i położnych, służącą konsolidacji środowiska } \\
\text { zawodowego. }\end{array}$ & $\begin{array}{l}\text { Strona poświęcona } \\
\text { edukacji }\end{array}$ \\
\hline 8. & $\begin{array}{l}\text { Ogólnopolski Zwiqzek } \\
\text { Zawodowy Pielegniarek } \\
\text { iPołożnych }\end{array}$ & 6458 & 1986 & $\begin{array}{l}\text { Storna reprezentuje największą pielęgniarką organizacje związkową, } \\
\text { zrzeszającą pielęgniarki z terenu całego kraju. Jej celem jest walka } \\
\text { o godne warunki pracy pielęgniarek, stosowanego gratyfikowania. }\end{array}$ & $\begin{array}{l}\text { Organizacja społeczna; } \\
\text { Firma z branży } \\
\text { medycznej }\end{array}$ \\
\hline 9. & $\begin{array}{l}\text { Pielęgniarki i położne } \\
\text { szanujcie się to inni będq } \\
\text { Was szanować }\end{array}$ & 5448 & brak danych & $\begin{array}{l}\text { Autor strony przyznaje się, iż nie jest pielęgniarzem ani pielęgniarką. } \\
\text { Jest rozczarowany traktowaniem oraz poziomem wynagrodzeń } \\
\text { pielęgniarek i położnych, co próbuje zmieniać poprzez aktywność } \\
\text { na stronie. }\end{array}$ & Społeczność \\
\hline 10. & Pielęgniarki na platformie & 5274 & brak danych & $\begin{array}{l}\text { Strona ma na celu informowanie o możliwościach edukacyjnych } \\
\text { dedykowanym pielęgniarkom oraz położnym. Fanpage motywuje } \\
\text { także do rozwoju zawodowego, podejmowania kształcenia } \\
\text { podyplomowego, szkoleń oraz kursów. }\end{array}$ & Edukacja \\
\hline
\end{tabular}


Kryteriami doboru stron była liczba obserwujących - like’ów (powyżej 5 tys.) oraz ich aktywność na portalu społecznościowym Facebook.com. Strony obserwowano przez okres 30 dni, w styczniu 2019, w dwudniowych interwałach czasowych, zwracając wagę na publikowane treści zarówno przez twórców jak i użytkowników portalu Facebook.com, w formie postów, komentarzy oraz wpisów. Kryteriami analizy przyjętymi w badaniu była: tematyka treści, cel publikowanych treści, atrakcyjność i spójność wizualna, język publikowanych treści, aktywność strony, tworzenie stałej społeczności odbiorców oraz promowany wizerunek zawodowy.

W lutym 2019 roku trzech autorów niezależnie poddało analizie wymienione strony, a następnie, otrzymane wyniki zostały poddane dyskusji i uzgodnieniu, biorąc pod uwage wymienione kryteria analizy.

\section{WYNIKI}

Tematyka postów analizowanych fanpage’y ma różnorodny charakter. Większość analizowanych stron skupia się przede wszystkim wokół samego pielęgniarstwa jako działalności praktycznej oraz dyscypliny naukowej związanej z ochroną zdrowia. Administratorzy promują informacje związane $\mathrm{z}$ warunkami pracy pielęgniarek, aktów prawnych ważnych dla środowiska zawodowego pielęgniarek i położnych, treści odnoszących się do możliwości dalszego kształcenia podyplomowego, szeroko pojętego rozwoju zawodowego. Fanpage'e przedstawiają aktualne wiadomości ważne zarówno dla pielęgniarek pracujących już w zawodzie, jak i dla studentów, młodych adeptów sztuki pielęgniarskiej. W czasie przeprowadzania obserwacji stron dominującą tematyką był poziom wynagrodzeń pielęgniarek i położnych, wizerunek zawodowy tych dwóch profesji, a także kwestie związane $\mathrm{z}$ działalnością danej organizacji, bądź osób będących autorami fanpage'y.

Kolejnym kryterium analizy był cel publikowania treści, będący bezpośrednio związany z ich tematyką. Niemalże wszystkim fanpage'om zakwalifikowanym do badania przyświecał cel informacyjny, dedykowany w szczególnej mierze grupie zawodowej pielęgniarek i położnych. Strony przedstawiały także dylematy codziennej pracy pielęgniarki, widziane oczami praktyka, co można utożsamić z celem motywacyjnym, skłaniającym do refleksji na temat zawodu pielęgniarki, jej wkładu w proces terapeutyczny, a także osobistych zaniedbań odbiorcy. Treści poruszające aspekty aktywności organizacji, jej promocji oraz procesu rekrutacji, wiązały się z realizacją celów statutowych grupy formalnej, którą dani zarządcy strony reprezentują.

W trakcie przeprowadzania analizy porównawczej zauważono, iż głównym, nadrzędnym celem każdej ze stron jest mobilizacja społeczeństwa do dyskusji nad zachodzącymi zmianami w środowisku zawodowym pielęgniarek, zwrócenie uwagi na ich sytuację w kraju, docenienie wkładu w całościowy proces terapeutyczny. Wiąże się to z koniecznością publikowania treści prowadzących do uwrażliwiania, zarówno samego środowiska zawodowego, jak i ogółu społeczeństwa, na problemy i wyzwania w pracy pielęgniarki, ze szczególnym zwróceniem uwagi na prawa pacjenta, a przede wszystkim na oczekiwania biorców opieki.
Atrakcyjność i spójność wizualna analizowanych stron jest na zróżnicowanym poziomie. Zdecydowana większość grafik, zdjęć cechowała się wysoką jakością. Niektóre z fanpage'y korzysta z profesjonalnych programów graficznych, bądź pomocy specjalistów w tej dziedzinie. Dominującą formą graficzną analizowanych stron były infografiki, służące szybszemu zapoznaniu użytkownika $z$ treścią, bez konieczności jej całościowego czytania. Zdjęcia z wydarzeń realizowanych przez organizację były równie często publikowane. Filmy, nagrania oraz transmisje na żywo, nie były często wykorzystywanym formantem publikowania. Poziom spójności wizualnej stron uzależniony był od poziomu profesjonalizmu szaty graficznej strony. Przy analizie fanpage’y pod względem ich atrakcyjności wizualnej szczególną uwagę zwrócono na avatar (zdjęcie profilowe) oraz cover photo (zdjęcie w tle), były one dostosowane do nazwy oraz treści witryny, jednak zdjęcia w tle w 4 przypadkach nie były dostosowane do wersji mobilnej aplikacji Facebook.com.

Jezzyk publikowanych treści w znaczący sposób wpływa na zainteresowanie dodawanymi postami. W sytuacji, gdy jest on prosty, cechuje go dostosowanie do grupy odbiorców (pielęgniarek i położnych oraz pozostałych czytelników, niezwiązanych ze środowiskiem medycznym) całość strony jest odbierana jako profesjonalna, chętniej czytana, a przede wszystkim prawidłowo rozumiana. Wyżej opisanym stylem wirtualnej komunikacji posługują się wszyscy autorzy analizowanych fanpage'y.

Aktywność analizowanych stron jest zróżnicowana, jednak większość $\mathrm{z}$ nich publikuje treści średnio raz na dwa, trzy dni. W grupie badanej znalazły się także fanpage, które umieszczają treści z mniejszą częstotliwością, to jest raz na kilka tygodni. Częstym zjawiskiem jest komasowanie treści jednego dnia, szczególnie w sytuacji trwania ważnych wydarzeń, dla organizacji, z którą dana strona jest powiązana, co może ograniczyć grupę odbiorców.

Przez tworzenie stałej społeczności odbiorców rozumie się prowadzenie rozmów w komentarzach, zachęcanie obserwatorów do wyrażenia własnego zdania, zadawania pytań, czy wysyłania wiadomości bezpośrednio do administratorów strony, z czym wiąże się wskaźnik czasu odpowiedzi redaktorów. Zdecydowana większość aktywnych obecnie stron systematycznie dokłada starań w angażowaniu „obserwujących” przez odpowiadanie na komentarze, zadawane pytania. Administratorzy storn odpowiadali zazwyczaj w ciągu jednego dnia od czasu otrzymania wiadomości od użytkownika portalu.

$\mathrm{Z}$ aspektem tworzenia społeczności odbiorców wiąże się również kolejny mierzalny przez witrynę Facebook.com wskaźnik to jest ocena strony dokonywana przez osoby ją obserwujące, w skali 1 do 5, gdzie 1 oznacza ocenę najsłabszą, zaś 5 ocenę maksymalną. Średnia ocena analizowanych storn mieściła się w granicach 4,5 - 5,0.

Promowany wizerunek zawodowy postrzegać można dwojako, w sposób pozytywny bądź negatywny. Wywieranie pozytywnego wrażenia na odbiorcach, dotyczącego pielęgniarstwa jest misją każdego z analizowanych fanpage’y. Ich redaktorzy zwracają uwagę użytkowników portalu Facebook.pl na problemy występujące nie tylko 
w środowisku zawodowym pielęgniarek, ale także w całym systemie ochrony zdrowia, ze szczególnym naciskiem na dobro pacjenta, uświadamiają społeczeństwu fakt niskiego prestiżu zawodu pielęgniarki, a przede wszystkim podkreślają ogromy wkład pracy przedstawicieli tej profesji w całościowy proces terapeutyczny każdego pacjenta. $\mathrm{Na}$ pozytywny odbiór strony ma również wpływ informowanie opinii publicznej o rzeczywistych warunkach pracy pielęgniarek, odbywających się debatach, rozmowach na temat proponowanych w środowisku zawodowym zmian. Brak nacechowania politycznego, burzliwych kłótni w komentarzach, obecność apeli o zaprzestanie deprecjonowania zawodu może pozytywnie wpłynąć na postrzeganie danej strony, jak i zawodu pielęgniarki. Pojawiające się na fanpage'ach rozwiązania problemów codziennej praktyki pielęgniarskiej, ogłoszenia o organizowanych kursach, szkoleniach, czy specjalizacjach mają największą ilość reakcji, co jest wskaźnikiem największego zainteresowania odbiorców właśnie tymi treściami.

Wśród komponentów, których obecność może negatywnie wpłynąć na postrzeganie pielęgniarek i położnych, wyróżnia się między innymi emanowanie negatywnymi cechami pielęgniarek. Może się to przyczynić do trudności w odnalezieniu dobrych stron tego zawodu przez społeczność portalu Facebook.com. Kontrowersyjne treści przesycone polityką, prowadzące do nieporozumień, dyskusji głównie za pomocą komentarzy przyczyniają się do deprywacji zawodu pielęgniarki. Częstym zjawiskiem stają się oskarżenia kierowane w stronę grupy zawodowej o brak solidarności w obliczu wyzwań, jakie stoją przed nim, niemalże każdego dnia.

\section{OMÓWIENIE WYNIKÓW}

Media społecznościowe mają duży wpływ na kreowanie wizerunku pielęgniarek. Autorzy za ich pośrednictwem mają szansę na poprawę wizerunku tego zawodu, zlikwidowanie stereotypizacji i wykreowanie prawdziwej, rzetelnej opinii o profesji pielęgniarki [8]. Są one także narzędziem komunikacji ze środowiskiem zewnętrznym organizacji, w tym oprócz pielęgniarek, również z osobami niezwiązanymi z tym zawodem.

Zdecydowana większość pielęgniarek, a przede wszystkim studentów kierunku pielęgniarstwo posiada konto na portalu społecznościom Facebook.com, w którym zamieszczane są informację o miejscu zatrudnienia, ukończonej uczelni, czy aktualnym miejscu edukacji zawodowej. Dodatkowo osoby te publikują różnego rodzaju treści, komentują, wyrażają opinie, udzielają się w kontrowersyjnych, dyskusjach. Każda z wymienionych aktywności, pomimo iż cechuje ją względna prywatność może mieć wpływ na wizerunek nie tylko samej osoby jej dokonującej, ale także organizacji, którą reprezentuje. Codziennością staje się weryfikacja na portalach społecznościowych potencjalnych pracowników czyniona przez pracodawców. W związku z powyższym wszelkie aktywności jednostki powinny być przemyślane, tak aby pozytywnie wpływały na jej przyszłe losy zawodowe oraz własny, osobisty wizerunek w Internecie [9]. Z wyników niniejszego badania wynika, iż autorzy stron mają świadomość tych kwestii, jednak społeczność „zgromadzona” wokół strony poprzez różnie zabarwione komentarze oraz język dyskusji często negatywnie wpływa na wizerunek własny, wykonywanego zawodu oraz fanpage'a.

Media społecznościowe w ocenie Royal College of Nursing (RCN) są świetną platformą do wymiany doświadczeń, poszerzania wiedzy oraz tworzenia społeczności ekspertów, do których użytkownicy mogą zwracać się w przypadku wątpliwości. W przyszłości może to przynieść wymierne korzyści nie tylko dla całego środowiska zawodowego pielęgniarek, ale i dla samego pacjenta [10].

Korzystanie z social media niesie za sobą także wiele zagrożeń, które zostały wymienione w anglojęzycznym Przewodniku odpowiedzialnego użytkowania mediów społecznościowych dedykowanym pielęgniarkom oraz położnym w Wielkiej Brytanii. Wskazuje on, iż niewłaściwe korzystanie z narzędzia, jakim jest portal Facebook.com może skutkować nawet pozbawianiem prawa do wykonywania zawodu pielęgniarki, poprzez między innymi: udostępnianie poufnych informacji, publikowanie zdjęć pacjentów, jednostek systemu opieki zdrowotnej bez ich zgody, zamieszczanie negatywnych komentarzy odnoszących się do pacjentów, nawiązywanie kontaktów z pacjentami bez ich wcześniejszej zgody i innych [11]. W analizie zgromadzonego materiału nie stwierdzono takiego zjawiska. Przestrzegano również standardów dotyczących ochrony prywatności miejsca pracy, intymności pacjentów oraz wszystkich współpracowników.

Korzystanie z social media jako narzędzia kształtowania wizerunku wiążę się z dużym ryzykiem popełniania błędu w strategii tworzenia komunikatów, grożących utratą wypracowanego w przeszłości wizerunku zawodowego. Ponad to ważnym elementem publikowania w Internecie jest przestrzeganie zapisów aktów prawnych normalizujących problematykę ochrony własności intelektualnej, czy naruszeniem dóbr osobistych. Należy podkreślić więc fakt, iż użytkownicy portali społecznościowych nie są anonimowi, a wszelka niekonstruktywna krytyka, szerzenie mowy nienawiści jest przestępstwem przeciwko art. 212 oraz art. 216 Kodeksu Karnego. Co więcej korzystanie z portali społecznościowych w czasie pracy, publikowanie zdjęć pochodzących z jednostek systemu ochrony zdrowia może wiązać się z możliwością dyscyplinarnego zwolnienia. Ważne jest zatem, aby podczas wykonywania czynności wynikających ze stosunku pracy zminimalizować korzystanie z portali społecznościowych do absolutnego minimum, chyba że są one narzędziem niezbędnym do wykonywania obowiązków zawodowych [9].

Analiza porównawcza przeprowadzona w niniejszym artykule prezentuje, iż w porównaniu do krajów Europy Zachodniej tematyka mediów społecznościowych w polskim pielęgniarstwie jest tematem nowatorskim. Brak jest polskich pozycji literaturowych wyjaśniających kwestie prawne związane z publikowaniem treści na witrynie Facebook.com. Wskazuje to na potrzebę intensyfikacji działań, służących przekazaniu instrukcji korzystania z mediów społecznościowych przez środowisko zawodowe pielęgniarek oraz innych profesjonalistów sektora ochrony zdrowia. Działania te powinny być oparte na edukacji. Warto przemyśleć również możliwość publikacji przewodnika 
korzystania z mediów społecznościowych, wzorując się na przykładzie wydanej przez Nursing and Midwifery Council (NMC) pozycji [11].

\section{WNIOSKI}

Zarówno pielęgniarki pracujące w zawodzie w realnej rzeczywistości, jak i te obecne w rzeczywistości wirtualnej współtworzą wizerunek własnej grupy zawodowej. Poddane analizie strony pielęgniarskie wykorzystują potencjał, jaki posiadają media społecznościowe w tej materii. Wśród czynników niekorzystanie wpływających na wizerunek pielęgniarek można wskazać m.in. obraźliwy język komentarzy osób obserwujących stronę, czy epatowanie negatywnymi cechami pielęgniarek. Pozytywne wrażenie gwarantuje natomiast widoczna w postach i komentarzach aktualna wiedza $\mathrm{z}$ zakresu pielęgniarstwa, ukazywanie rzeczywistych warunków pracy, a także podkreślanie kompetencji zawodowych i zaangażowania pielęgniarek w proces terapeutyczny. Istnieje potrzeba dalszych badań dotyczących zagadnienia kształtowania wizerunku zawodu pielęgniarki w mediach społecznościowych.

\section{REFERENCES/PIŚMIENNICTWO}

1. Słownik Języka Polskiego PWN www.sjp.pwn.pl/sjp/;2579940 [dostęp z dnia 11.03.2019].

2. Włodarczyk D, Tobolska B. Wizerunek zawodu pielęgniarki z perspektywy lekarzy, pacjentów i pielęgniarek. Med Pr. 2011; 62 (3): 269-279.

3. Kapała A, Kapała W. Wizerunek pielęgniarki, czyli jak widzą i oceniają ciebie inni? W cieniu czepka. Biuletyn informacyjny Dolnośląskiej Okręgowej Izby Pielęgniarek i Położnych 2018; 2/316: 16 - 19.

4. Żychowska R. Wizerunek polskiej pielęgniarki i położnej w mediach publicznych i prywatnych oraz w prasie zawodowej. Materiały z międzynarodowej konferencji „Wizerunek pielęgniarki i położnej na tle nowych wyzwań w pielęgniarstwie polskim i europejskim" Warszawa: Wyd. Naczelna Rada Pielęgniarek i Położnych 2009, s. 37-47.

5. Markiewicz E, Resiak-Urbanowicz M. Kształtowanie wizerunku przedsiębiorstwa w Internecie na przykładzie międzynarodowych targów poznańskich. Studia Oeconomica Posnaniensia. 2014; 2 (3): 196-216.

6. Badzińska E. Media interaktywne warunkiem skutecznej komunikacji społecznej. Nierówności Społeczne a Wzrost Gospodarczy 2013; 35: 24-40.

7. Kojder E, Zarzycka D. Wizerunek zawodowy pielęgniarki i jego determinanty. Piel XXI w. 2014; 2(47): 47-52.

8. Sykut A, Dobrowolska B. Media elektroniczne i ich wpływ na kreowanie wizerunku zawodowego pielęgniarek według opinii pracujących przedstawicieli tej profesji. Pielęg Pol. 2016; 3 (61): 347-352.

9. Kaczmarek-Śliwińska M. Kompetencje medialne pracowników w dobie social media. Kul Popul. 2014; 3 (41): 68-77.

10. Sainsbury J. How can nursing students use social media to enhance their studies and future career? www.rcn.org.uk/news-and-events/blogs/making-the-most-ofsocial-media [dostęp z dnia 11.03.2018].

11. Guidance on using social media responsibly. Nursing and Midwifery Council (NMC): www.nmc.org.uk/globalassets/sitedocuments/nmc-publications/social-mediaguidance.pdf [dostęp z dnia: 11.03.2019].

Manuscript received/Praca zgłoszona do czasopisma: 25.03.2019

Manuscript accepted/Praca zaakceptowana do druku: 20.05.2019

Translation/Tłumaczenie: Beata Chrust 